\title{
Frequency of stress lesions of the upper gastrointestinal tract in paediatric patients after cardiac surgery: effects of prophylaxis
}

\author{
R Behrens, M Hofbeck, H Singer, J Scharf, T Rupprecht
}

\begin{abstract}
Background-Stress lesions of the upper gastrointestinal tract are well recognised in adult patients in intensive care. There are no controlled studies of the incidence of these lesions and the effects or side effects of prophylactic treatment in high risk paediatric patients.

Methods-79 paediatric patients in intensive care were studied prospectively after operation for congenital heart disease. All patients had at least one endoscopic examination. The first 36 patients were not given prophylactic medication: later 43 children were treated randomly either with pirenzepine $(n=21)$ or with famotidine $(n=22)$. Gastric and tracheal secretions were taken daily for culture in those patients given prophylactic medication.

Results-Severe inflammation or ulceration of the upper gastrointestinal tract was less common in those patients who were given prophylactic medication $(18 \%$ $v 44 \%$ ). Prophylactic treatment did not, however, reduce the total incidence of postoperative stress lesions: it shifted the severity of these changes towards mild lesions and reduced the incidence of ulcerations from $25 \%$ to $2 \%$. None of the patients developed a pneumonia caused by an organism previously isolated from the stomach.

Conclusions-The incidence of stress lesions in children after cardiac surgery resembles that in high risk adult patients. Children in intensive care after cardiac surgery should be treated prophylactically with famotidine or pirenzepine until they can be fed by mouth.
\end{abstract}

Department of Gastroenterology, University Children's Hospital, Erlangen,

Germany

R Behrens

Department of

Cardiology

M Hofbeck

$\mathrm{H}$ Singer

Department of

Intensive Care

Medicine

J Scharf

T Rupprecht

Correspondence to

Dr R Behrens, University

Children's Hospital,

Department of Pediatric

Gastroenterology,

Loschgestrasse 15, D-91045

Erlangen, Germany.

Accepted for publication

22 November 1993
(Br Heart f 1994;72:186-189)

Stress-induced lesions of the upper gastrointestinal (GI) tract often develop in adults in intensive care units. Lesions include diffuse or petechial bleeding, erosions, severe inflammation, ulcerations, and perforations. ${ }^{12}$ Predisposing risk factors are septic or hypovolaemic shock, cerebrocranial trauma, and extensive surgery. ${ }^{3-5} \mathrm{Up}$ to $75 \%$ of adult patients in intensive care develop a lesion of the upper GI tract. ${ }^{7}$ Prophylaxis with antacids, $\mathrm{H}_{2}$ antagonists, or pirenzepine reduced the incidence of these lesions to $16-20 \% .^{8-10}$

Antacids and $\mathrm{H}_{2}$ antagonists increase the gastric $\mathrm{pH}$ to $>4$. Pirenzepine is an anticholinergic agent that is highly specific for $M 1$ receptors of the stomach and reduces the production of hydrogen ions in the gastric mucosa. In addition it improves perfusion of the gastric mucosa, which leads to an increased production of mucus and bicarbonate, ${ }^{11}$ but does not change the gastric $\mathrm{pH}$.

There is evidence, however, that prophylactic treatment with antacids or $\mathrm{H}_{2}$ antagonists promoted bacterial overgrowth in the stomach and thus increased the risk of nosocomial pneumonia in adults. ${ }^{1213}$

Stress-induced ulcers of the upper gastrointestinal tract were detected in infants by pathological examinations in $1926 .{ }^{14}$ Nevertheless, so far there have been no controlled studies of the incidence of stress lesions and the effects of prophylactic treatment in infants and children in intensive care. ${ }^{15}$ The purpose of our study was to obtain reliable data about the incidence of these lesions and about effects and side effects of prophylactic treatment in infants and children who underwent surgery for congenital heart disease.

\section{Patients and methods}

From October 1988 until November 1991 we prospectively examined 79 consecutive children who underwent corrective or palliative surgery for congenital heart disease. We did not include patients who had operations that usually have a short and uncomplicated postoperative recovery such as repair of an atrial septal defect, valvotomy for aortic stenosis, or repair of coarctation of the isthmus. The first 36 patients (group 1) were not given treatment to prevent lesions of the upper GI tract. Later, 43 patients (group 2) were randomised and treated either with pirenzepine, an anticholinergic, (21 patients) or famotidine, a $\mathrm{H}_{2}$ antagonist, (22 patients). Both drugs were given intravenously at a dosage of 1 $\mathrm{mg} / \mathrm{kg} /$ day. In older patients the drugs were given as two doses; children who weighed $<10 \mathrm{~kg}$ were given three doses. The daily dosage was reduced to $0.5 \mathrm{mg} / \mathrm{kg}$ if the serum creatinine concentration exceeded $3 \mathrm{mg} / \mathrm{dl}$. Prophylactic treatment was continued in all patients until they were fed fully by mouth.

Table 1 shows the diagnoses and the type of cardiac surgery. Except for six patients in group 1, cardiac surgery was performed with cardiopulmonary bypass. All patients had at least one endoscopic examination performed by the same examiner (RB) using endoscope (Pentax) with an outer diameter of $5.5 \mathrm{~mm}$ or $8.0 \mathrm{~mm}$. If a patient had more than one examination, we based our assessment on the 
Table 1 Type of congenital heart disease and surgical procedures

\begin{tabular}{llcc}
\hline & Surgical & Group & \multicolumn{2}{c}{ Group } \\
Diagnosis & procedure & 1 & 2 \\
\hline AVSD & Patch closure & 6 & 15 \\
AVSD & Pulmonary banding & 1 & - \\
VSD & Patch closure & 10 & 5 \\
VSD & Pulmonary banding & 1 & - \\
D-TGA & Senning procedure & 4 & 5 \\
ToF & Corrective surgery & 2 & 3 \\
ToF & Aortopulmonary shunt & 1 & - \\
DORV & Intracardiac repair & 1 & 3 \\
TA & Fontan procedure & 2 & 2 \\
TA & Aortopulmonary shunt & 1 & - \\
TAC & Rastelli procedure & 2 & 1 \\
TAPVD & Corrective surgery & - & 2 \\
SV & Fontan procedure & - & 2 \\
PA & Outflow tract patch & - & 1 \\
PA & Aortopulmonary shunt & 1 & -4 \\
Miscellaneous & & 4 & 4 \\
Total: & & 36 & 43 \\
\hline
\end{tabular}

Table 2 Endoscopic score describing the severity of upper GI tract lesions

\begin{tabular}{ll}
\hline Category & Score \\
\hline $\begin{array}{l}\text { Normal findings } \\
\text { Mild to moderate } \\
\text { inflammation, few }\end{array}$ & 0 \\
petechiae or & \\
$\quad$ erosions \\
$\begin{array}{l}\text { Pronounced } \\
\text { inflammation, multiple } \\
\text { petechiae or }\end{array}$ & 1 \\
$\quad$ erosions & 2 \\
Ulcer(s) & 3 \\
\hline
\end{tabular}

Table 3 Clinical score describing the postoperative state

\section{Score A}

(1) Stable haemodynamic condition (intravenous catecholamines)

(2) No respiratory problems under mechanical ventilation

(3) Normal renal function

1) Unstable Score B

haemodynamic condition requiring high dose intravenous catecholamines or

(2) State after cardiac arrest, resuscitation, or repeat thoracotomy or

(3) Renal failure requiring haemodialysis or haemofiltration

Table 4 Data on 79 patients

\begin{tabular}{lcc}
\hline Data & Group 1 & Group 2 \\
\hline No of patients & 36 & 43 \\
Mean age (y) & $3 \cdot 12$ & $2 \cdot 62$ \\
Male & $(10$ days-19.9 yr) & $(35$ days-9.85 yr) \\
Female & 15 & 24 \\
Mean weight (kg) & 21 & 19 \\
Mean cardiopulmonary bypass time (min) & $11 \cdot 02$ & $11 \cdot 47$ \\
Mean aortic cross clamp time (min) & 142 & $(3 \cdot 7-42)$ \\
Mean interval between surgery and gastroscopy & 67 & 146 \\
$\quad$ (days) & 6 & 70 \\
Patients in stable haemodynamic condition & 22 & 4 \\
$\quad$ (clinical score A) & 25 & 25 \\
$\quad$ (clinical score B) & 14 & 18 \\
\hline
\end{tabular}

defect; D-TGA defect; D-TGA, d-transposition of the great arteries; ToF, tetralogy of Fallot; DORV, double-outlet right ventricle; TA TAPVD, total anomalous pulmonary venous drainage; SV, single ventricle; PA, pulmonary atresia.

examination that showed the most severe changes. The examination was performed while the patients still required mechanical ventilation. Patients did not need additional sedation for the endoscopic examination at this time because continuous intravenous fentanyl $(0.02 \mu \mathrm{g} / \mathrm{kg} / \mathrm{min})$ and intravenous midazolam $(0.1 \mathrm{mg} / \mathrm{kg} / \mathrm{h})$ were given routinely. All patients were treated with antibiotics after operation (cefuroxime or cefotiam at a dose of $100 \mathrm{mg} / \mathrm{kg} / \mathrm{day}$ ). At the time of endoscopy they were given full parenteral nutrition, because enteral nutrition was impossible in the immediate postoperative period. Total parenteral nutrition and routine intensive care were identical in both groups.

To assess the severity of lesions of the upper GI tract we developed a score based on the endoscopic findings (table 2). To correlate the endoscopic findings with the clinical course, patients were classified according to a clinical score describing the state of the patient at the time of examination (table 3 ). In addition patients in group 2 had continuous 24 hour measurement of $\mathrm{pH}$ (Synectics Medical, Stockholm, Sweden). The probe was placed endoscopically in the body of the stomach. While patients were being treated with pirenzepine or famotidine daily samples of tracheal and gastric secretions were cul- tured for pathogenic bacteria by the Institute of Clinical Microbiology, University of Erlangen-Nürnberg. All patients had daily routine chest $x$-rays on the first three postoperative days. Afterwards chest $x$-rays were taken if indicated by the clinical findings.

The $\chi^{2}$ and the Wilcoxon tests were used for statistical analysis. Exclusion criteria were participation in another clinical trial during the past 30 days, a history of upper GI tract lesions, leucopenia of $<3500 / \mu \mathrm{l}$ or thrombocytopenia (platelets $<65000 / \mu \mathrm{l}$ ). Informed consent was obtained from all parents before the study. Only two patients were excluded because their parents refused their consent.

The study was approved by the ethics committee on human research of the University of Erlangen-Nürnberg.

\section{Results}

Age, weight, cardiopulmonary bypass time, aortic cross clamp period (table 4) and mean interval between endoscopy and cardiac surgery were not significantly different in the two groups (Wilcoxon test). The clinical course of patients in both groups was similar. According to our clinical score (table 3) $61 \%$ of patients in group 1 and $58 \%$ of patients in group 2 were in a stable haemodynamic condition (score A). Furthermore statistical analysis of group 2 did not show a significant difference of these variables between those patients who were treated with famotidine and those treated with pirenzepine.

Table 5 shows results of endoscopy. Normal findings or only mild inflammatory reactions (endoscopic score grade 0 or 1 ) were present in a higher percentage of patients in group 2 than in group 1 (81\% v 56\%). Although there was no difference between both groups in those patients who showed pronounced inflammation (19\% in group $1 v$ $16 \%$ in group 2 ), ulceration was much more common in group 1 patients $(25 \% v 2 \%$ in group 2). Normal findings or mild lesions were more common in group 2 and pronounced inflammation or ulceration were more common in group $1\left(\alpha_{,}^{2} \mathrm{P}<0.05\right)$.

In both groups the postoperative course correlated with the severity of upper GI tract lesions. Most patients with an uncomplicated postoperative course in both groups (47 patients classified as clinical score A) either had normal findings or mild inflammatory changes (group $173 \%$, group $292 \%$ ). In those children with a more complicated postoperative course (32 patients classified as clinical score B), pronounced inflammation or ulceration was found in $71 \%$ of patients from group 1 and in $33 \%$ of patients from group 2 . Those differences were statistically significant $\left(\chi^{2}, P<0.005\right)$. In the group 2 patients there were no differences between those treated with pirenzepine and those treated with famotidine.

Patients in group 2 who were treated with pirenzepine had a significantly lower mean gastric $\mathrm{pH}$ during 24 hour monitoring than patients who were treated with famotidine 


\begin{tabular}{|c|c|c|c|c|c|}
\hline $\begin{array}{l}\text { Endoscopic } \\
\text { score }\end{array}$ & $\underset{1}{\text { Group }}$ & $\begin{array}{l}\text { Group } \\
2\end{array}$ & & $\begin{array}{l}\text { Pirenzepine group } \\
\text { (stomach/trachea) }\end{array}$ & $\begin{array}{l}\text { Famotidine group } \\
\text { (stomach/trachea) }\end{array}$ \\
\hline $\begin{array}{l}0 \\
1 \\
2 \\
3\end{array}$ & $\begin{array}{r}2 \\
18 \\
7 \\
9^{\star}\end{array}$ & $\begin{array}{c}1 \\
34 \\
7 \\
1+\end{array}$ & $\begin{array}{l}\text { Candida spp } \\
\text { Enterobacter spp } \\
\text { Streptococcus spp } \\
\text { Pseudomonas aeruginosa }\end{array}$ & $\begin{array}{r}12 / 3 \\
6 / 8 \\
1 / 7 \\
3 / 3\end{array}$ & $\begin{array}{r}10 / 8 \\
9 / 3 \\
5 / 8 \\
2 / 3\end{array}$ \\
\hline \multirow{2}{*}{\multicolumn{3}{|c|}{$\begin{array}{l}\text { * Site of ulceration in } \\
\text { patients in group 1: oeso- } \\
\text { phagus ( } n=2), \text { stomach } \\
\text { ( } n=6), \text { duodenum }(n=1 \\
\text { including one perforation). } \\
\text { +Site of ulceration in group } \\
\text { 2: stomach }(n=1) \text {. }\end{array}$}} & $\begin{array}{l}\text { Acinetobacter spp } \\
\text { Staphyloccocus spp } \\
\text { Klebsiella spp } \\
\text { Escherichia coli } \\
\text { Serratia marcescens } \\
\text { Haemophilus influenzae } \\
\text { Bacteroides spp } \\
\text { Veillonella spp } \\
\text { Aerobic spore forming } \\
\text { bacilli } \\
\text { Campylobacter freundii }\end{array}$ & $\begin{array}{l}1 / 2 \\
1 / 2 \\
0 / 2 \\
0 / 1 \\
1 / 0 \\
0 / 1 \\
- \\
- \\
- \\
-\end{array}$ & $\begin{array}{l}3 /- \\
2 / 1 \\
2 /- \\
2 /- \\
0 / 1 \\
- \\
1 /- \\
1 /- \\
1 /- \\
1 /-\end{array}$ \\
\hline & & & Total & $27 / 32$ & $43 / 23$ \\
\hline
\end{tabular}

$\left(2.18 v 6 \cdot 20, \chi^{2}, \mathrm{P}<0.001\right)$. Three patients from each group, however, had unexpected high or low mean $\mathrm{pH}$ values (mean $\mathrm{pH}>4$ in children treated with pirenzepine or mean $\mathrm{pH}<4$ in children treated with famotidine).

In children from group 2 cultures of gastric secretion were positive in $95 \%$ of patients with a mean gastric $\mathrm{pH}>4$ and in $80 \%$ of patients with a mean gastric $\mathrm{pH}<4\left(\chi^{2}, \mathrm{NS}\right)$. Table 6 shows the type and number of organisms cultured from gastric and tracheal secretion. An organism cultured from the stomach was grown from tracheal secretion one to four days later in six patients $(29 \%)$ treated with pirenzepine and in five children treated with famotidine $(23 \%)$. Nine patients treated with pirenzepine and four patients treated with famotidine had high temperatures in the early postoperative period. In one patient coagulase negative staphylococci were grown from blood cultures; in the rest of the patients all cultures were negative. Only one patient from the pirenzepine group developed pneumonia, which was diagnosed on the third postoperative day. None of the nine patients treated with pirenzepine had an organism cultured from tracheal secretion that was previously isolated from the stomach.

\section{Discussion}

Stress lesions of the upper GI tract develop in up to $75 \%$ of adult high risk patients. ${ }^{67}$ Considerable variation in the reported incidence can be explained by the fact that not all of the studies were based on the results of endoscopic examinations and that some patients were being fed by mouth, which protects to some extent against those lesions. ${ }^{1617}$ In paediatric patients upper GI tract lesions have been described in case reports ${ }^{18}$ and in retrospective studies. ${ }^{19-21}$

This is the first prospective study reporting the incidence of these stress lesions based on endoscopic findings in a homogenous group of paediatric patients in intensive care after surgery for congenital heart disease. Thirty four $(94 \%)$ of those patients who did not receive prophylactic treatment had stress lesions of the upper GI tract. There were severe lesions in $44 \%$ of these children who had either pronounced inflammation (19\%) or even ulceration (25\%). One patient required surgical treatment of a perforated duodenal ulcer. The incidence of stress lesions in children after cardiac surgery resembles that in adults at high risk.

We believe that the effects of prophylactic treatment can be gauged only by endoscopic findings. There are several studies of prophylactic treatment in babies and children but none includes the results of routine endoscopy. ${ }^{22-24}$ Our study confirms previous observations in adult patients that there is a positive correlation between the incidence of upper GI tract lesions and the severity of the underlying disease. ${ }^{10}$ Severe changes were noted in only $17 \%$ of children with an uncomplicated postoperative course; whereas $50 \%$ of children in whom recovery took longer had pronounced inflammation or ulceration. In these high risk patients the incidence of severe stress lesions was significantly reduced in children who received prophylactic treatment compared with those who did not $(33 \% v$ $71 \%)$. Though in our experience prophylactic treatment does not reduce the total incidence of postoperative stress lesions, it promotes a shift in the severity of those changes towards mild lesions with a considerable reduction in the incidence of ulcerations $(25 \%$ of untreated patients and $2 \%$ of patients given prophylaxis had ulcers). There have been several reports of a higher incidence of nosocomial pneumonias in adult patients treated with $\mathrm{H}_{2}$ antagonists or antacids. ${ }^{1325}$ This was attributed to an increase in bacterial colonisation of the stomach caused by an increase in gastric $\mathrm{pH}^{26}$ We believe that the results of some of those studies are questionable because they included a high percentage of patients who were already at an increased risk of nosocomial pneumonias (for example, patients who had a tracheostomy ${ }^{27}$ or patients who were mechanically ventilated for a long time $^{28}$ ). Usually changes in gastric $\mathrm{pH}$ were recorded as single measurements despite the fact that a protective bactericidal effect was reported in patients who had a gastric $\mathrm{pH}$ of $<3$ for at least 15 minutes. ${ }^{29}$ Different studies can be compared only if patients are examined under standardised conditions including endoscopic examination, continuous 24 hour $\mathrm{pH}$ measurement, repeat cultures from tracheal and gastric secretion, and standardised oral or parenteral nutrition. These criteria were fulfilled in our patients who received prophylactic treatment with either pirenzepine or famotidine. During 24 hour $\mathrm{pH}$ measurement $20 \%$ of our patients who were treated with famotidine had periods of gastric $\mathrm{pH}$ of $<3$ lasting more than 15 minutes. Without continuous measurement such periods of bactericidal gastric $\mathrm{pH}$ would not have been detected. None of our patients developed pneumonia caused by an organism previously isolated from the stomach.

Our study confirms the results from Cook et $a l^{30}$ who found that prophylactic treatment 
of upper GI tract lesions does not increase the risk of nosocomial pneumonia. Because medical treatment reduced the risk of severe stress lesions we recommend prophylactic medication with either famotidine or pirenzepine in all high risk patients after corrective surgery of congenital heart disease. In our experience those at high risk are children in unstable haemodynamic condition who require high doses of intravenous catecholamines, children after cardiac arrest, resuscitation, or repeat thoracotomy, and children in whom renal failure requiring haemodialysis or haemofiltration develops.

1 Greenburg AG. Stress ulcera. World f Surg 1981;5:148-9. Koelz HR, Aeberhard P, Hassler H, Kunz H, Wagner HE Roth F, et al. Prophylactic treatment of acute gastroduodenal stress ulceration. Scand $\mathcal{f}$ Gastroent 1987;22: 1147-52.

3 Taylor PC, Loop FD, Hermann RE. Management of acute stress ulcer after cardiac surgery. Ann Surg 1972 178:1-5.

4 Le Gall JR, Mignon FCh, Rapin M, Redjemi M, Harari A, Bader JP, et al. Acute gastroduodenal lesions related to

5 Kamada T, Fusamoto H, Kawano S, Nogushi M, Hiramatsu $\mathrm{K}$, Masuzawa $\mathrm{M}$, et al. Gastrointestina
bleeding following head injury: A clinical study of 433 cases. F Trauma 1977;17:44-7.

6 Zuckermann GR, Shuman R. Therapeutic goals and treatment options for prevention of stress ulcer syndrome. ment options for prevention of stress

7 Gyr K, Meier R. Stressulkuskrankheit und deren Prophylaxe. Schweiz Med Wochenschr 1989;119:423-9.

8 Rohde H, Lorenz W, Fischer M. Eine randomisierte klinische Studie zur Stressulkusprophylaxe mit Cimetidin che Studie zur Stressulkusprophylaxe mit Cimetidin
beim schweren Polytrauma. Z Gastroenterol 1980;18: beim s.

9 Zinner MJ, Zuidema GD, Smith PL, Mignosa M. The prevention of upper gastrointestinal tract bleeding in patients in an intensive care unit. Surg Gynecol Obste 1981;153:214-20.

10 Breucha G, Imhof $M$. Pirenzepin in der Allgemeinchirurgie. INA 1987;59:81-7.

11 Tryba M, Zevounou F, Wruck G. Stressblutungen und post-operative Pneumonien bei Intensivpatienten unter Ranitidin oder Pirenzepin. Dtsch Med Wochenschr 1988, 113:930-3.
12 Du Moulin GC, Hedley-White J, Paterson DG, Lisbon A Aspiration of gastric bacteria in antacid-treated patients: a frequent cause of postoperative colonisation of the airway. Lancet 1982;i:242-7.

13 Driks MR, Craven DE, Celli BR, Manning M, Burke RA Garvin GM, et al. Nosocomial pneumonia in intubated patients given Sucralfat as compared with antacids or histamine type 2 blockers. $N$ Engl $f$ Med 1987;317: 1376-82.

14 Kennedy RLJ. Etiology and healing process of duodenal ulcer in melena neonatorum. Am $\mathscr{f}$ Dis Child 1926;31: 631-8.

15 Cichowicz E, Alvarez-Ruiz JR. Acute upper gastrointestinal bleeding in children. Bol Assoc Med $P R$ 1985;75: 214-20.

16 Pingleton SK, Hadzima SK. Enteral alimentation and gastrointestinal bleeding in mechanically ventilated patients. Crit Care Med 1983;11:13-7.

17 Valentine RJ, Turner WW, Borman KR, Weigelt JA. Does nasoenteral feeding afford adequate gastroduodenal nasoenteral feeding afford adequate gastroduoden

18 Zamir O, Hadary A, Goldberg M, Nissan S. Spontaneous perforation of the stomach in the neonate. $Z$ Kinderchir 987;42:43-5.

19 Spencer $R$. Gastrointestinal hemorrhage in infancy and childhood: 476 cases. Surgery 1964;55:718-34

20 Kumar D, Spitz L. Peptic ulceration in children. Surg Gynecol Obstet 1984;159:63-6.

21 Barron PT, Watters JM, Wesley-James T. Perforated ulcers in critical illness. Crit Care Med 1987;15:584-6.

22 Lacroix J, Infante-Rivard C, Gauthier M, Rousseau E, van Doesburg N. Upper gastrointestinal tract bleeding acquired in a pediatric intensive care unit: Prophylaxis trial with cimetidine. F Pediatr 1986;108:1015-8.

23 Hartemann E, Berthier JC, Gerbier F. Assessment of intragastric $\mathrm{pH}$ in critically ill children. Effects of ranitidine [abstr]. Int Care Med 1987;13:448.

24 Eddlestone JM, Booker PD, Green JR. Use of ranitidine in children undergoing cardiopulmonary bypass. Crit Care Med 1989;17:26-9.

25 Tryba $M$. The risk of acute stress bleeding and nosocomial pneumonia in ventilated ICU-patients. Sucralfate versus pneumonia in ventilated ICU-patients. Sucralfate v
antacids. $A m \mathcal{F}$ Med 1987;83(suppl 3B):S117-S24.

26 Nachtkamp J, Bares R, Winkeltau G, Klinge U, Schumpelick V, Büll U, et al. Keimbesiedlung des Magens unter medikamentöser Streßprophylaxe-Ursache von bronchopulmonalen Infektionen bei Beatmungsvon bronchopulmonalen Infektionen

27 Cross AS, Roup B. Role of respiratory assistance devices in endemic nosocomial pneumonia. Am $₹ \mathrm{Med} 1981 ; 70$ $681-5$

28 Inthorn D, Seide K. Ursachen und Prognose des respiratorischen Versagens chirurgischer Intensivpatienten Münch Med Wochenschr 1985;127:1006-9.

29 Petersen K-U. Protonenpumpenhemmung zur Behandlung peptischer Läsionen. Dt Ärztebl 1991;88:4012-3.

30 Cook DJ, Laine LA, Guyatt GH, Raffin TA. Nosocomial pneumonia and the role of gastric $\mathrm{pH}$. A metaanalysis. Chest 1991;100:7-13. 